\title{
First report of Choanephora infundibulifera causing blossom blight of teasle gourd in India
}

\author{
SIDDHARTHA DAS ${ }^{\prime \#}$, SUBRATA DUTTA ${ }^{1 *}$, ARUP CHATTOPADHYAY ${ }^{1}$ and BHOLANATH MANDAL ${ }^{2}$ \\ ${ }^{1}$ Department of Plant Pathology, AICRP on Vegetable Crops, Directorate of Research, Bidhan Chandra Krishi Viswavidyalaya, \\ Kalyani, Nadia 741 235, West Bengal, India \\ ${ }^{2 \sharp D e p a r t m e n t ~ o f ~ P l a n t ~ P r o t e c t i o n, ~ V i s v a-B h a r a t i-P a l l i ~ S i k s h a ~ B h a v a n a, ~ B i r b h u m ~} 731$ 235, West Bengal, India
}

Received: 21 April 2017/ Accepted: 31 May 2017/ Published online: 31 May 2017

CIndian Phytopathological Society 2017

\begin{abstract}
Momordica subangulata Blume subsp. renigera (G. Don) de Wilde is an important vegetable in India. In June 2015, blossom blight symptoms of Momordica subangulata subsp. renigera was first time noticed in the experimental plot of Directorate of Research, Bidhan Chandra Krishi Vishwavidyalaya, Kalyani, West Bengal, India. The disease severity ranged from $10-30 \%$ and the disease infection was also recorded from several other districts of West Bengal, India. The disease is caused by zygomycetous fungi, Choanephora infundibulifera (Currey) sacc. is the main causal organism of blossom blight disease. The temperature $28-30^{\circ} \mathrm{C}$ with high humidity $(70-90 \%)$ prevalent during the rainy season (June-November) favoured the disease development. This is the first report of blossom blight of Momordica subangulata subsp. renigera caused by Choanephora infundibulifera.
\end{abstract}

Keywords: Choanephora infundibulifera, ITS, Momordica subangulata, monosporous, sporangiola

Momordica subangulata Blume subsp. renigera (G. Don) de Wilde (family-Cucurbitaceae) is the perennial vegetable with high food value and medicinal importance. It is native of Asia with extensive distribution in all the states of India. During June-November 2015, blossom blight of Momordica subangulata subsp. renigera was first time noticed in the experimental plot of Bidhan Chandra Krishi Viswavidyalaya, Kalyani, West Bengal, India (Fig. 1). The disease severity ranged from 10-30\% in the farm area. Symptoms appeared as black pin head like emerging sporangiola, formed a cushiony mat on blossom.
The peak disease infection was recorded from the month of June to September in 2015. Previously it was known that plant pathogenic zygomycetes are weak parasites (Agrios, 2005), but some zygomycetous fungi evolved their behavior in such a way that their complex adoptability prefers new host range as a substitution of their trend line. The genus Choanephora, a member of Zygomycetes is known to attack withering floral parts of many plants after fertilization and invades the fruits, causing a soft rot of primarily summer squash or pumpkin, pepper and okra (Agrios, 2005). Isolation of the pathogen was done from the infected plant part or

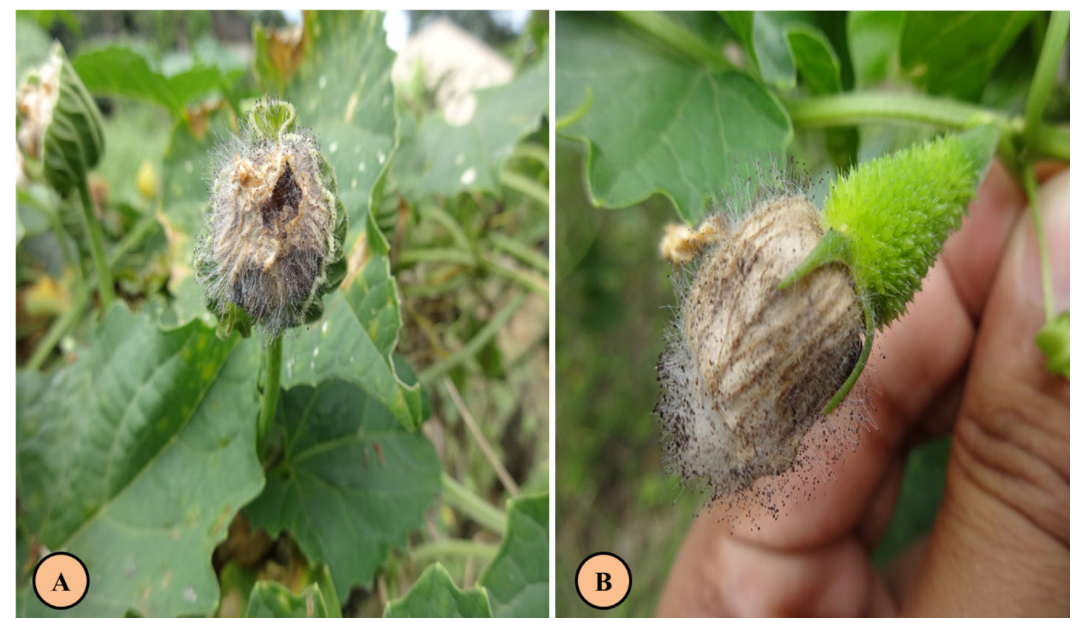

Fig. 1. Blossom blight of Momordica subangulata subsp. renigera with emerging sporangiola (A) Initial stage (B) Mature stage 


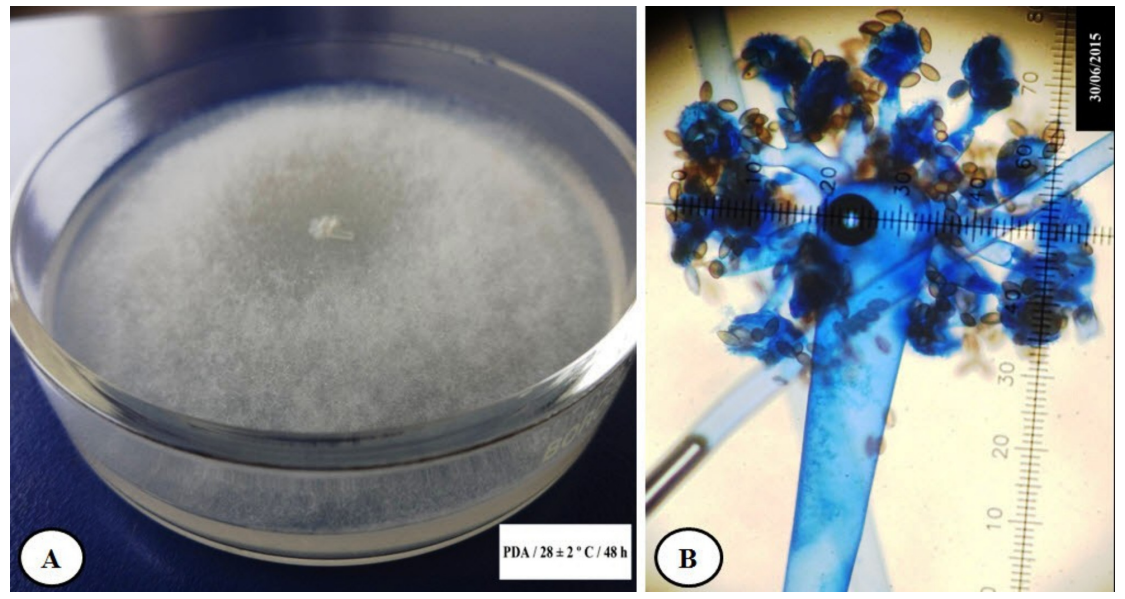

Fig. 2. (a) Choanephora infundibulifera culture on PDA, (b) Single sporangiola

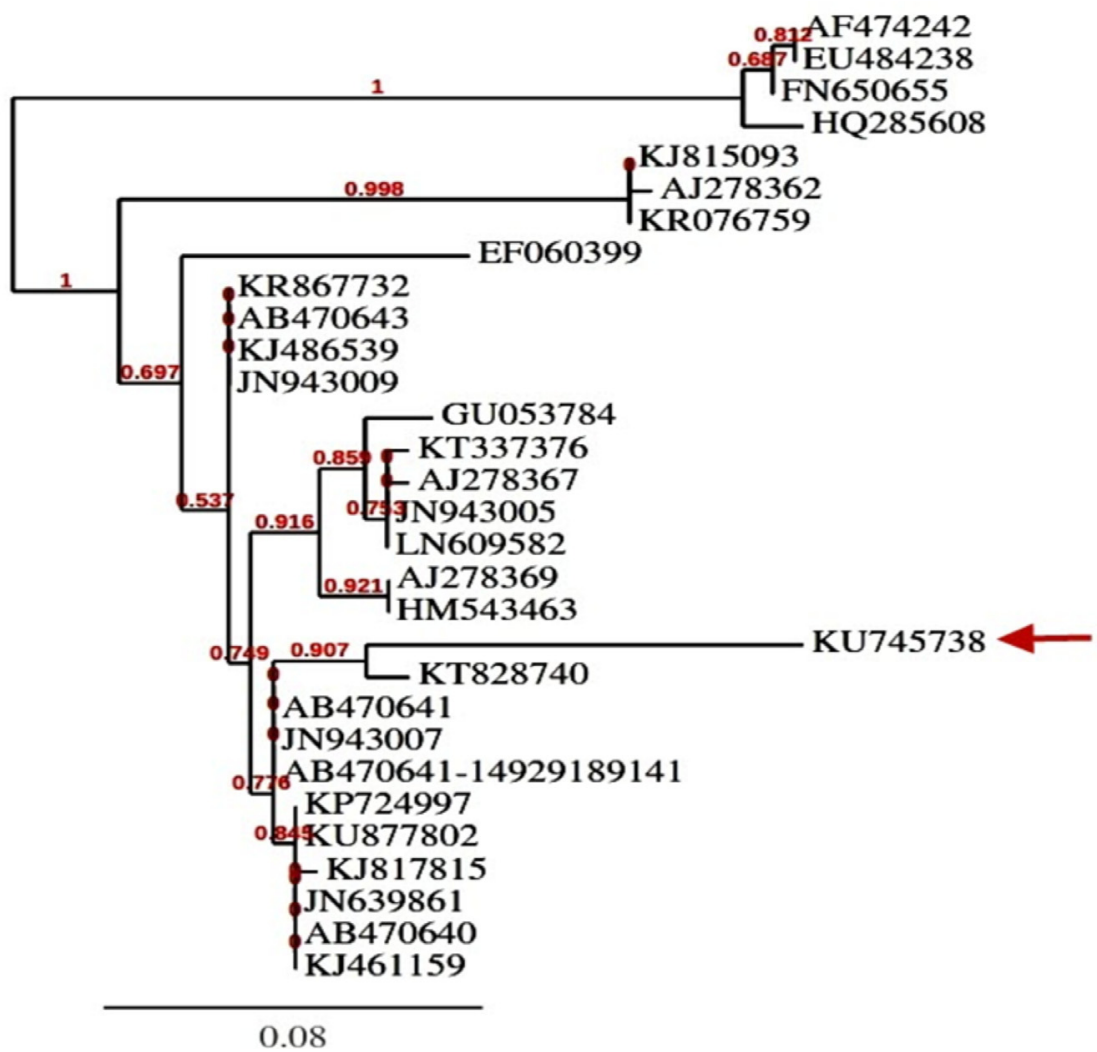

Fig. 3. The sequence generated on the present study showed a maximum likelihood search in RAxML with an alignment of the 16S rDNA region using MEGA version 6

singly emerging sporangiola on PDA medium and maintained at $28 \pm 2^{\circ} \mathrm{C}$. The pathogen preferred monsoon or rainy season with high moisture (70-90\%). Creamish white colored culture shows yellow pigmentation at maturity due to $\beta$-carotene synthesis. Pathogenecity test of the isolate M.D-9 was confirmed by cross-inoculation of seven different isolates by single mycelial disc inoculation technique. Among three different isolates, host specific isolates M.D-2 and M.D-9 showed virulence.

To fulfill Koch's postulates and confirm its pathogenicity, detached leaf assay was performed in respect of three isolates - M.D-9, Cow-6 and Br-2. Host specific isolate M.D-9, gave the highest virulence with sporulation and proved pathogenic.

Morphological studies revealed that sporangia were sub-globose in shape and 40.2-118.5 $\mu \mathrm{m}$ in size. There are two types of sporangiola i.e., monosporus and multisporus sporangiola. Monosporus sporangiola were elliptic, fusiform, or ovoid in shape, pediculate, striate, and 8.5-24.5 $\times$ 6.5-13.5 $\mu \mathrm{m}$ in size (Fig. 2). Sporangiospores were elliptic, fusiform or ovoid (6.5-11.5 $\times 10-30 \mu \mathrm{m})$, brown, with or without three or more thin appendages at both ends. 
Based on morphological characterization the fungus was identified as Choanephora infundibulifera. The herbarium specimen of infected plant and culture of the isolate M.D-9 was deposited in $\mathrm{HClO}$ (Herbarium Cryptogamae Indiae Orientalis, HClO No. 52020) and ITCC (Indian Type Culture Collection, ITCC No. 7904) at ICAR-Indian Agricultural Research Institute, New Delhi, India.

For molecular characterization, genomic DNA was extracted from fungal mycelium of M.D-9 isolate using CTAB DNA extraction method (Wu et al., 2001). Internal transcribed spacers (ITS) of the ribosomal DNA of M.D9 isolate was amplified by using the primer pair, ITS-1 and ITS-4 (White et al., 1990). The resulting sequence of 622 bp DNA was deposited in Genbank and assigned with the accession number KU745738. Homology searching with BLAST tool of NCBI-Gen bank fungal database (of ITS-r DNA region), exactly matches with publicly available Choanephora infundibulifera sequence. Results showed that the KT828740 (India) and JN 943007 (India) remains in the same cluster and nearest. The phylogenetic analysis was done by using MEGA version 6 (Fig. 3).

C. infundibulifera is a dioecious mucoraceous fungus. Previously Choanephora was considered as a weak pathogen or saprophyte, but day by day its improved infectious behavior, as well as increased host range (including different plant families), turned out to be a major pathogen in the domain of West Bengal's present agro-climatic situation. Although it has been previously reported on different crops to cause pod rot of Vigna sinensis (Kwon et al., 2001b), blossom blight of
Petunia (Kwon et al., 2001a), flower rot of Hibiscus mutabilis (Kwon and Park, 2002). Based on literature this is the first report of blossom blight of Momordica subangulata subsp. renigera.

\section{ACKNOWLEDGEMENTS}

The authors are thankful to Dr. T. Prameela Devi and Dr. Diwakar Bahukhandi, ITCC, Division of Plant Pathology, ICAR-Indian Agricultural Research Institute, New Delhi, India for their assistance, support and cooperation.

\section{REFERENCES}

Agrios GN (2005). Plant Pathology, $5^{\text {th }}$ ed. Academic Press. San Diego, CA. USA

Kwon JH, Kang SW, Kim JS and Park CS (2001a). Occurrence of blossom blight of Petunia caused by Choanephora cucurbitarum. Res. Plant Dis. 7: 112-115.

Kwon JH and Park CS (2002). Flower rot of cotton rose (Hibiscus mutabilis) caused by Choanephora cucurbitarum. Res. Plant Dis. 8: 55-58.

Kwon JH, Shen SS and Park CS (2001). Pod rot of cowpea (Vigna sinensis) caused by Choanephora cucurbitarum Korea. Plant Pathol J. 17: 354-356.

White TJ, Bruns TD, Lee SB and Taylor JW (1990). Amplification and sequencing of fungal ribosomal RNA genes for phylogenetics. In: Innis N, Gelfand D, Sninsky J, White TC (Eds.) PCR protocols and applications - a laboratory manual. Academic, New York.

Wu ZH, Wang TH, Huang W and QU YB (2001). A simplified method for chromosome DNA preparation from filamentous fungi. Mycosystema 20: 575-577. 